DOI https://doi.org/10.36059/978-966-397-235-0-2

Бондаренко О. В.,

кандидат юридичних наук

м. Київ

\title{
УНІВЕРСАЛЬНІ МІЖНАРОДНО-ПРАВОВІ ДОКУМЕНТИ ПРО СВОБОДУ СОВІСТІ ТА ЗАХИСТУ ВІД НЕТЕРПИМОСТІ І ДИСКРИМІНАЦІЇ ТА КСЕНОФОБІЇ: ПРОБЛЕМИ ТА ПЕРСПЕКТИВИ РОЗВИТКУ
}

\begin{abstract}
Анотація. Метою проведення зазначеного наукового дослідження $\epsilon$ визначення, аналіз і узагальнення структури та змісту універсальних міжнародно-правових документів про свободу совісті та захисту від нетерпимості і дискримінації та ксенофобії.
\end{abstract}

За результатами дослідження автор зазначає, що недотримання принципу світоглядного нейтралітету держав створює підгрунття для конфліктів, а значить, і вкрай серйозні перешкоди на шляху позитивної інтеграції держав.

Вчора і сьогодні міжнародне право, а сьогодні $і$ завтра глобальні правові механізми, спрямовані на реалізацію прав людини, толерантність $i$ захист від нетерпимості $i$ дискримінації, повинні стати фундаментом трансформації політичних систем, ціннісних орієнтацій, формування глобального мислення і переходу до сталого розвитку цілісного безполярного світу.

Серед стратегічних напрямків для зміни ситуації на краще слід виділити такі: розробка сучасної теоретико-правової моделі свободи совісті на основі нової парадигми (моделі), що усуває суперечності основоположних принципів і понятійного апарату; реформування універсальних міжнародно-правових документів у сфері свободи совісті на основі сучасної теоретико-правової моделі; реформування регіональних міжнародно-правових документів у сфері свободи совісті на основі сучасних теоретикоправових моделей $i$ універсальних міжнародно-правових документів; реформування внутрішньодержавного правового інституту свободи совісті на основі сучасних теоретикоправових моделей $і$ міжнародно-правових документів; 
Права людини в Україні та у зарубіжних країнах: традиції та новації

формування $i$ вдосконалення міжнародно-правової $i$ внутрішньодержавної системи гарантій реалізації свободи совісті на основі принципу світоглядного нейтралітету держав та інших суб'єктів міжнародного права.

Розробка спеціального законодавства у галузі захисту свободи совісті та захисту від нетерпимості $і$ дискримінації та ксенофобії забезпечить реалізацію принципу правової визначеності в суспільстві, зменшить конфлікт між людьми, які беруть участь у цих відносинах, і може призвести до підвищення якості механізмів захисту прав людини.

\section{Вступ}

Глобалізація соціальних відносин пов'язана з трансформацією національного суверенітету та формуванням глобальних підсистем, рівень розвитку яких не однорідний, що породжує порушення балансу, соціальний патерналізм, конфлікти i потрясіння.

У зазначеному контексті не менш важливою і складною задачею $є$ формування глобального мислення, оскільки майбутнє залежить від того, чи зможуть люди подолати соціальні розбіжності.

Реалізація прав людини (і особливо, права свободи совісті, як системоутворюючого права в системі прав людини) виступає необхідною умовою скорочення і подолання розриву між владою і суспільством, еволюційного обмеження влади одних людей над іншими, i, в кінцевому підсумку, виступає втіленням свободи людини, як об'єктивної вимоги сучасному глобалізму суспільних відносин. Державний суверенітет повинен поступатися, в кінцевому підсумку, на користь людини. Це означає, що права людини $\epsilon$ пріоритетом сучасного міжнародного права i формується на його основі глобального права.

У міру трансформації правових і політичних систем теоретико-правове поняття і зміст свободи совісті сприймає загальнонаукову тенденцію до розширення, звільняючись від прив'язки до юридично невизначених категорій «релігія», «віросповідання». Свобода совісті стала розглядатися через призму прав і свобод людини, виступаючи в якості юридичної основи свободи особистості.

Сучасне розуміння свободи совісті включає в себе все різноманіття форм та систем світоглядної орієнтації. Оскільки 
Права людини в Україні та у зарубіжних країнах: традиції та новації

правового визначення релігії не існує, тому свободу віросповідання слід розглядати не тільки як складову частину свободи совісті, а й як їі визначальний елемент. У зазначеному аспекті свобода совісті є основоположним невід'ємним правом кожного на задоволення світоглядної потреби, надає сенс існуванню на основі вільного світоглядного вибору, а також правомірної поведінки, заснованої на згаданому виборі без обмеження в інших цивільних правах і свободах або їх втрати.

Світськість держави, як її світоглядний нейтралітет, $\epsilon$ найважливішою гарантією реалізації свободи совісті та захисту від дискримінації. Відповідно, порушення принципу світськості нівелює як окремі види гарантій реалізації свободи совісті, так і систему гарантій в цілому.

Підхід, позначений вище, відображає еволюцію уявлень, яка простежується від перших концепцій віротерпимості в Стародавньому світі до ідей релігійної свободи та вільнодумства, що зародилися в епоху феодалізму і далі отримали розвиток в політичних і правових поглядах XV-XX ст. Найбільш очевидними показниками стану реалізації свободи совісті $\epsilon$ численні порушення прав індивідів і об'єднань, які проявляються у формі дискримінації, нетерпимості, ксенофобії та насильства на їх грунті.

Під нетерпимістю і дискримінацією на основі релігії або особистих переконань прийнято розуміти будь-яке розмежування. Поняття «ксенофобія» теоретично розроблено вкрай слабо і в правовій системі України не застосовується. Відповідно, взаємозв'язок протиправних діянь і ксенофобських поглядів, під якими вони вчинені, не завжди очевидний i питання коректності її вияву є дискусійним.

Серед універсальних документів з прав людини, які зачіпають сферу свободи совісті і спрямованих на захист від нетерпимості і дискримінації, слід виділити: Статут ООН, Загальну декларацію прав людини, Міжнародний пакт про громадянські і політичні права; Міжнародний пакт про економічні, соціальні і культурні права; Декларацію про ліквідацію всіх форм нетерпимості та дискримінації на основі релігії або переконань; Декларацію про права осіб, що належать до національних або етнічних, релігійних і мовних меншин; Конвенцію про права дитини; Конвенцію про боротьбу з дискримінацією в галузі освіти; Декларацію принципів толерантності та ін. 
Права людини в Україні та у зарубіжних країнах: традиції та новації

Ми розглянули різні підходи закордонних вчених в проблематиці свободи совісті та захисту від нетерпимості і дискримінації та ксенофобії за останні декілька років.

\section{1. Міжнародно-правові гарантії захисту права на свободу совісті та захист від нетерпимості і дискримінації та ксенофобії}

Міжнародно-правові документи займають центральне місце в системі міжнародного захисту прав людини. На думку Роббертса Р., «права людини - один з різновидів суб'єктивних прав особи. У сучасному розумінні права людини - найбільш істотні іï можливості розвитку, невід'ємні властивості, що визначають міру їі свободи». [1, с. 78] У багатьох роботах Р. Роббертса обгрунтовується ідея формування нової науки науки прав людини [1, с. 85].

Л. Ярмол, обгрунтовуючи необхідність розвитку теорії прав людини, вважає, що «сучасний світ неможливо уявити без прав людини, які засновані на принципах свободи, рівності, справедливості і носять універсальний характер», і говорить про важливість регіональних механізмів захисту прав людини [2; с. 75].

Як зазначає А. Камал, «в широкому сенсі права людини пов'язані з питанням співвідношення інтересів суспільства і людини. Кожна людина $\epsilon$ частиною суспільства і повинна розглядатися ним і державою як особистість, що має цінність і право на повагу до своєї гідності ... Якщо виходити з того, що метою суспільства і держави $є$ утвердження принципу гуманізму, то інтереси людини повинні бути поставлені на перше місце» [3].

Говорячи про інтернаціоналізацію зазначених прав в результаті прийняття міжнародних документів, Л. Ярмол зазначає, що вони були «юридично визнані більшістю держав світу, був сформований юридичний механізм їх захисту» [4, с. 114]. Т. Мендель також справедливо зазначає, що «принцип поваги основних прав і свобод став одним 3 найважливіших принципів міжнародного права. Як і $є$ нова галузь міжнародного права, що визначає обов'язки держави щодо забезпечення всім людям, незалежно від раси, мови, релігії, статі, основних прав і свобод» [5].

Таким чином, міжнародний захист прав людини, як сукупність принципів і норм, що регулюють захист прав і основних свобод індивіда, $\epsilon$ однією 3 найважливіших галузей сучасного міжнародного публічного права. 
Як вважає С. Лайтхард, «міжнародний захист прав людини становить собою здійснення співробітництва держав за двома основними напрямками: по-перше, створення універсальних i регіональних міжнародно-правових норм в області прав людини, по-друге, створення і реалізацію спеціальних механізмів контролю за їх дотриманням» [6]. В. Счабас вважає, що «прагнення захищати людську гідність всіх людей $\epsilon$ ядром концепції прав людини. Воно ставить людину в центр уваги. Воно засноване на загальній універсальній системі цінностей, присвяченій недоторканності життя, що надає основу для побудови системи прав людини, захищеної міжнародноприйнятими нормами і стандартами. Протягом 20-го століття права людини розвивалися як моральна, політична і юридична основа і керівництво для розвитку вільного від страху і бідності суспільства» [7].

Все це говорить про те, що «метою, критерієм прогресивного суспільного і державного розвитку є людина, реальність її прав, свобод в поєднанні з обов'язками і відповідальністю за свою поведінку» [8], а також, що «між забезпеченням державами основних прав і свобод людини і підтриманням міжнародного миру і безпеки існує тісний зв'язок» [9].

Становлення даної галузі відбувалося протягом тривалого історичного періоду i не можна сказати, що цей процес завершено. Питання дотримання прав людини розглядалися в рамках Ліги Націй і включалися в двосторонні і багато-сторонні договори держав. На принципово новому рівні захист прав людини було закріплено в документах Організації Об'єднаних Націй (OOH), членами якої є більшість держав світу.

У Статуті ООН, що заклав основу сучасного міжнародноправового захисту і прийнятому 26 червня 1945 року, говориться про рішучість «позбавити майбутні покоління від лиха війни, яку двічі перенесло людство, і знову затвердити віру в основні права людини, в гідність і цінність людської особистості, в рівноправність чоловіків і жінок і в рівність прав великих і малих націй i створити умови, при яких можуть дотримуватися справедливість і повага до зобов'язань, що випливають 3 договорів та інших джерел міжнародного права, сприяти соціальному прогресові і поліпшенню умов життя при більшій свободі» [10]. 
Права людини в Україні та у зарубіжних країнах: традиції та новації

Слід особливо відзначити зобов'язання держав-членів ООН «здійснювати міжнародне співробітництво у вирішенні міжнародних проблем економічного, соціального, культурного i гуманітарного характеру та в поширенні і розвитку поваги до прав людини і основних свобод для всіх, незалежно від раси, статі, мови і релігії» [10].

Таким чином, «за допомогою Статуту, всі держави-члени ООН юридично пов'язані в боротьбі за повну реалізацію всіх прав i свобод людини» [10], що фактично означає міжнародне визнання принципу поваги прав людини. Цей принцип отримав подальший розвиток в різних міжнародно-правових документах як універсального, так і регіонального характеру.

Загальна декларація прав людини, прийнята резолюцією 217А (III) Генеральної асамблеї ООН від 10 грудня 1948 року, «зіграла ключову роль в подальшому розвитку механізму прав людини і стала основою, на якій була побудована міжнародна система захисту і приведення в життя прав людини» [11].

Стаття 1 Загальної декларації прав людини, згідно з якою «всі люди народжуються вільними і рівними у своїй гідності та правах. Вони наділені розумом і совістю і повинні діяти у відношенні один до одного в дусі братерства». Відповідно до статті 2 «кожна людина повинна мати всі права і всі свободи, проголошені Декларацією, без будь - якої різниці, як-то: в відношенні раси, кольору шкіри, статі, мови, релігії, політичних чи інших переконань, національного або соціального походження, майнового, соціального або іншого становища. Крім того, не повинно проводитися ніякого розмежування на основі політичного, правового або міжнародного статусу країни або території, до якої людина належить, незалежно від того, чи $\epsilon$ ця територія незалежною, підопічною, несамоврядованою або обмеженою у своєму суверенітеті» [12].

На думку А. Ковбан, галузь міжнародного права прав людини (вважаємо таке найменування більш коректним) «умовно можна розділити на дві частини: перша включає питання, пов'язані 3 громадянством, його придбанням, зміною та втратою, подвійного громадянства і безгромадянства; правами іноземців, осіб без громадянства, біженців, вимушених переселенців; правом притулку ... Друга частина зазначеної галузі включає міжнародні стандарти в сфері прав людини, діяльність 
міжнародних організацій в сфері забезпечення та захисту прав і свобод людини і громадянина» [13, с. 28].

Як зазначає I. Мишчак, «міжнародно-правові стандарти - це різновид міжнародних норм, що мають правовий характер, і $\epsilon$ складовою частиною системи норм міжнародного права. Отже, мова йде про стандарти, що мають міжнародно-правове значення. Однак частина міжнародних положень, хоча і має ознаки стандартів, ще не має юридичної сили, вони відіграють роль рекомендацій і ними користуються ті чи інші органи держав в односторонньому порядку» [14, с. 3]. Вчений також дає визначення універсальним міжнародно-правовим стандартам, відзначаючи, що «це певні правила поведінки, які визнаються державами всього міжнародного співтовариства або переважною їх більшістю» $[14$, с. 5]. Особливо акцентується увага на тому, що до згаданих стандартів відноситься і «один з основних принципів міжнародного права - принцип поваги прав людини і основних свобод, включаючи свободу думки, совісті, релігії і переконань»

I. Когут виділяє права людини, зафіксовані в International Bill of Rights, вважаючи, що «є міжнародні стандарти, нижче яких рівень забезпечення цих прав в окремих державах не допустимий» [15].

у роботах інших авторів під стандартами прав людини, спрямованих на розвиток принципу поваги прав людини, як правило, розуміються «загальновизнані норми поведінки держав, які останні повинні реалізувати в законодавстві i практиці по відношенню до всіх осіб, які перебувають під їх юрисдикцією» [16].

Правильніше говорити не про міжнародні стандарти в сфері прав людини, закріплені в міжнародних документах, а про загальновизнані права людини. Термін «загальновизнані права людини» більш точно відображає роль міжнародно-правових актів: вони виробляються на міждержавному рівні, призначаються для регулювання міждержавного співробітництва, адресуються в першу чергу державам, які в змозі забезпечити в межах своєї юрисдикції повагу до прав людини та несуть відповідальність перед своїм народом, перед міжнародним співтовариством за дотримання прав людини» [17]. Е. Дейс-Хелбіг вважає, що «закріплення в міжнародних документах прав людини робить їх міжнародно визнаними тобто зобов'язаннями держав» [17]. Даний автор вказує на «три рівні джерел загальновизнаних прав людини: 1. Міжнародні 
Права людини в Україні та у зарубіжних країнах: традиції та новації

джерела загальновизнаних прав людини. 2. Регіональні джерела загальновизнаних прав людини. 3. Національні джерела загальновизнаних прав людини» [17].

К. Данн у своїх роботах обгрунтовує виділення наступних форм міжнародного права: 1) основні принципи міжнародного права; 2) міжнародні договори; 3) звичаї міжнародного права. Дослідник вважає, що «джерелом міжнародних договорів є угоди держав та інших уповноважених суб'єктів міжнародного права. Джерелом основоположних (загальних) принципів міжнародного права виступає діяльність держав i уповноважених спеціалізованих установ (організацій), а також звичаї як повторювані дії суб'єктів міжнародного права щодо захисту своїх інтересів, забезпечені наявними правовими та іншими формами примусу» [18].

Дійсно, міжнародний рівень захисту прав людини тісно пов'язаний 3 внутрішньодержавним рівнем, а питання про напрям і характер впливу міжнародного права на національне право $є$ одним з базових. Цілий ряд дослідників відзначає, що в умовах глобалізації загальнодержавних відносин поглиблення взаємодії міжнародного і національного права (в т. ч. в сфері прав людини) носить об'єктивний характер.

На думку Х. Демпстер, «ефективність міжнародно-правових норм у багатьох випадках залишається ще досить невисокою. У багатьох напрямах співпраці вони часом порушуються. I що особливо важливо відзначити, ці порушення мають місце в сферах, пов'язаних з підтриманням миру, безпеки, захистом прав людини, захистом навколишнього середовища і т.д. Недостатньо ефективні (або зовсім неефективні) норми міжнародного права, які забороняють застосування сили в міжнародних відносинах, втручання у внутрішні справи суверенних держав, по боротьбі 3 міжнародним тероризмом і іншими злочинами міжнародного характеру» [20]. Недостатня ефективність міжнародно-правових документів говорить про те, що «значний потенціал, закладений в міжнародному праві, ще далеко не повністю реалізується на практиці, i багато потрібно зробити для розвитку i для підвищення його ефективності» [21].

3 урахуванням значення в умовах глобалізації суспільних відносин особливе занепокоїння викликає вкрай актуальна проблема підвищення ефективності міжнародних документів в сфері прав людини, в т. ч. свободи совісті. У контексті 
вищесказаного перспективним $є$ дослідження ролі міжнародного права не тільки в регулюванні міжнародних відносин, а й у вирішенні глобальних проблем, що загрожують самому існуванню людської цивілізації.

На особливу увагу заслуговує проблема ефективності міжнародно-правових документів у сфері свободи совісті, оскільки саме етноконфесійний фактор $€$ одним 3 основних перешкод на шляху до інтеграції держав для вирішення згаданих проблем. Для опису сучасного стану та динаміки суспільних відносин все частіше використовується термін глобалізація, під яким розуміється інтеграція планетарних взаємодій в якусь єдину систему і яка має тенденцію до усунення кордонів.

Деякі аспекти, пов'язані зі свободою совісті і захистом від нетерпимості і дискримінації, зачіпаються в таких документах: Декларація про права осіб, що належать до національних або етнічних, релігійних і мовних меншин від 18 грудня 1992 р; Конвенція про права дитини прийнята резолюцією 44/25 Генеральної Асамблеї від 20 листопада 1989 року і $\epsilon$ обов'язковою для держав-учасників (вступила в сили 2 вересня 1990 року). Конвенції передувало прийняття в 1959 році Генеральною Асамблеєю ООН Декларації про права дитини; Конвенції про боротьбу з дискримінацією в галузі освіти, що носить рекомендаційний характер (була прийнята Генеральною конференцією ООН з питань освіти, науки в культури на їі одинадцятій сесії 14 грудня 1960 року), Декларації принципів толерантності (затвердженої резолюцією 5.61 Генеральної конференції ЮНЕСКО від 16 листопада 1995 року). Крім згаданих вище, деякі аспекти, пов'язані зі свободою совісті і захистом від нетерпимості і дискримінації, зачіпаються в: Конвенції про запобігання та покарання за злочини геноциду 1948 роки; Конвенції про статус біженців 1951 року; Конвенції про статус апатридів 1954 року, Конвенції про ліквідацію всіх форм дискримінації щодо жінок 1979 року і ін.

Розгляд універсальних міжнародно-правових документів дозволяє зробити ряд висновків. Основні універсальні міжнародно-правові документи з'явилися важливими кроками на шляху утвердження принципів свободи совісті та захисту від нетерпимості i дискримінації, але їх слабким місцем був i залишається понятійний апарат. 
Спроби подолання численних суперечностей у сфері свободи совісті, вжиті Комітетом ООН з прав людини, своєї мети досягли не повністю. Доводиться констатувати, що Зауваження загального порядку Комітету ООН з прав людини № 22 (48) «Свобода думки, совісті і релігії» (стаття 18) і № 23 (50) - «Права меншин користуватися своєю культурою, сповідувати свою релігію і виконувати ії обряди» не підвищили ефективність відповідних міжнародно-правових документів. Світськість держави (як іï світоглядний нейтралітет), будучи найважливішою гарантією реалізації свободи совісті та захисту від нетерпимості і дискримінації, ніяк не визначена в міжнародно-правових документах. Це фактично нівелює згадані міжнародно-правові документи, роблячи їх декларативними.

\section{2. Значення свободи совісті для досягнення толерантності} та подолання дискримінації, нетерпимості та ксенофобії за мотивами світоглядної приналежності

Розгляд проблеми ефективності міжнародно-правових документів у сфері прав людини, і особливо це стосується сфери свободи совісті, нерозривно пов'язане з комплексом теоретикоправових питань.

Визнаючи внесок попередників, доводиться констатувати недостатність науково-теоретичної розробки проблеми свободи совісті та суміжних категорій. Зокрема, недостатньо розробленими $€$ питання співвідношення «свободи совісті» із пов'язаними 3 нею поняттями «свободи віросповідання», «світськості держави», «релігійної політики держави», «відносин держави з релігійними об'єднаннями» і ін.

Невирішеність проблеми співвідношення вищезазначених понять 3 поняттям «свободи совісті» призводить до юридично некоректного трактування принципів і понятійного апарату, в результаті чого «релігійна політика держави» i «відносини держави з релігійними об'єднаннями» стали пріоритетними по відношенню до «свободи совісті».

Серйозною проблемою $\epsilon$ питання застосування в системі права дискусійних термінів релігієзнавчої науки: «традиційні релігії (релігійні організації)», «нетрадиційні релігії (релігійні організації)», «секта», а також понять «духовна безпека», «релігійний екстремізм», «ісламський екстремізм» і т.п.

У свою чергу, ступінь наукової розробленості значно впливає на формування міжнародно-правових документів. Зокрема, обмежене тлумачення свободи совісті в законотворчості та 
Права людини в Україні та у зарубіжних країнах: традиції та новації

правореалізації спочатку зумовлює відсутність правових гарантій для осіб, які не є членами релігійних організацій, i, перш за все, «невіруючих».

Ситуація ускладнюється відсутністю і принциповою неможливістю формування єдиного юридичного визначення «релігії». Можливість множинного тлумачення терміна «релігія» зумовлює складність у сфері застосування цього терміна. У зв'язку із цим набуває актуальності питання правомірності державної релігієзнавчої експертизи, і застосування релігієзнавчих знань у вирішенні питань правового характеру. Питання про коректність правових понять похідних від терміна «релігія» (наприклад, «релігійне об'єднання») також $\epsilon$ дискусійним. Вимагає прояснення тісно взаємопов'язана 3 проблемою реалізації свободи совісті категорія «світськість держави», яка нерідко ототожнюється 3 «секуляризмом», i визначається як «нерелігійна». Видається актуальним усвідомлення значення реалізації свободи совісті для досягнення толерантності та подолання дискримінації, нетерпимості та ксенофобії за мотивами світоглядної приналежності.

Вкрай загострилася, як на міжнародному, так i на внутрішньодержавному рівнях, проблема впливу етноконфесійних факторів на забезпечення безпеки.

Згадані проблеми вимагають дослідження 3 урахуванням сучасного характеру суспільних відносин. Очевидно, що будь-які нормативні матеріали повинні збігатися з науковим розробкам. У зазначеному контексті вкрай загострюється проблема ефективності міжнародно-правових документів у сфері свободи совісті.

Теоретико-правове поняття і зміст свободи совісті формувалося і трансформувалося тривалий історичний період. Цей процес продовжується і сьогодні. Слід відразу зазначити, що механічне складання понять «совість» і «свобода» не дає адекватного розуміння терміну «свобода совісті» як суспільного явища. Якщо поняття «свобода» закріпилося в юридичній науці, то термін «совість» не має однозначної правової трактування, і не $є$ елементом системи правового регулювання. Як категорія етики, совість характеризує здатність особистості здійснювати моральний самоконтроль, самостійно формулювати для себе моральні обов'язки, вимагати від себе їх виконання і проводити самооцінку своїх вчинків.

Свобода совісті нерозривно пов'язана 3 поняттям індивідуальної свободи, яка є найважливішою складовою свободи особистості. За справедливою позицією М. Дистаціо, індивідуальна свобода, що реалізується поза державними рамками, 
«опосередковує і проявляється в системі соціальних зв'язків і відносин, що виражають такі важливі невід'ємні від особистості блага, як недоторканність життя, гідність, совість, особиста безпека людини. Специфічна особливість індивідуальної свободи (на відміну від політичної, економічної, культурної) в тому, що вона втілює індивідуально унікальні можливості людини і забезпечує можливості для самовизначення особистості. Справжня індивідуальна свобода означає заборону протиправного втручання в приватне життя громадян, заперечення тоталітарного контролю над індивідуумом» [22]. У свою чергу, індивідуальна свобода втілюється в цивільних правах людини. Ці права ідентифікують особистість, сприяють найкращому прояву духовних інтересів, схильностей, особистих здібностей. Вони гарантують можливість безперешкодного вибору різних варіантів поведінки в сфері індивідуальної свободи.

Слід зазначити, що в юридичній науці немає єдиної думки про місце свободи совісті в системі прав людини. Наприклад, К. Данн відносить свободу совісті до особистих прав і свобод, а X. Демпстер - до культурних прав. М. Дистаціо відносить право на свободу думки, совісті і релігії до цивільних прав. На думку автора, свобода совісті як свобода світоглядного вибору $\epsilon$ основою свободи як такої, системоутворюючим правом в системі прав людини. Видається не зовсім коректним говорити, що одне право $\epsilon$ більш важливим в порівнянні з іншим. Але без належної реалізації свободи совісті вся система прав людини може опинитися під загрозою.

Обмеження свободи совісті супроводжується підвищенням ризиків переходу до безальтернативної політичної системи, до авторитаризації влади, до масових порушень прав людини, до зростання ксенофобії, нетерпимості, дискримінації і насильства на їх грунті.

Ще одна проблема, яка не має однозначного і загальноприйнятого теоретичного тлумачення, пов'язана з використанням юридичних конструкцією «свобода совісті» i «право на свободу совісті». При цьому обидві конструкції нерідко використовуються в законодавстві і правозастосовчій практиці в якості синонімів.

У контексті проблеми реалізації свободи совісті автор солідаризується з думкою Л. Вонг, який вважає, що право на свободу совісті $\epsilon$ іï юридичним втіленням. У свою чергу, юридичне закріплення є лише однією з умов досягнення свободи совісті. Свобода совісті є явищем багатоплановим, що зачіпають 
Права людини в Україні та у зарубіжних країнах: традиції та новації

різні сторони життєдіяльності суспільства. Відповідно, існують багаточисельні підходи до розуміння свободи совісті.

Вперше аспектний підхід був запропонований Л. Вонг, який вважає, що «багатоаспектний характер цієї свободи зумовлює той факт, що вона може бути об'єктом вивчення різних суспільних наук: філософії, етики, політології, юриспруденції» [23].

Н. Зубашвілі залежно від зв'язку із загальною методологією тій чи іншій сфери суспільного знання виділяє два основних види підходів: «1) відносно незалежні (аксіологічний, конкретноісторичний і конкретно-юридичний підходи); а також 2) ті, що знаходяться в рамках окремої сфери суспільного знання. Останні умовно можна розділити на два типи: а) розглядають свободу совісті переважно в зв'язку 3 окремим індивідом, його переконання-ми, свідомістю, совістю, тобто в цілому - мораллю, яка може бути як релігійною, так і нерелігійною (теологічний, етичний підходи); б) співвідносяться дану свободу в першу чергу з громадськими відносинами, в які вступає індивід, коли його свобода обмежується точно такою ж свободою інших осіб (соціологічний, політологічний, правознавчий, релігієзнавчий, філософський)» [24].

Зміщення акценту з філософських аспектів свободи совісті в бік правових відбувається в міру трансформації правових i політичних систем. Більш того, воно взаємно впливає на цю трансформацію. За словами С. Фіар, «визнання основоположного принципу свободи думки і совісті змітає з лиця землі стару епоху ієрархії влади» [25]. На думку автора, свобода совісті все більше стала розглядатися через призму прав і свобод людини, які знайшли своє вираження в юридичних джерелах як окремих держав, так і міжнародного співтовариства в цілому.

Подібна закономірність ілюструє перехід від природних прав до права позитивного, від прав суб'єктивних до об'єктивного права. Тобто загальна тенденція така, що право поступово перестає бути інструментом держави з управління соціальними процесами і все більше стає гарантом свободи кожної людини в суспільстві і державі. I роль свободи совісті тут - першочергова. Полягає ця роль в тому, що свобода совісті, будучи позитивно закріпленою свободою індивіда в світоглядній і поведінковій сферах, виступає юридичною основою свободи особистості в сучасній правовій державі і громадянському суспільстві.

На міжнародному рівні ідеали свободи віросповідання завоювали визнання у всьому світі, і не применшуючи їх значення, доводиться констатувати, що самостійні поняття, закріплені Загальною декларацією прав людини та іншими 
Права людини в Україні та у зарубіжних країнах: традиції та новації

міжнародними документами (Міжнародним пактом про громадянські і політичні права (Прийнято Генеральною асамблеєю ООН 16 грудня 1966 р.), Європейською конвенцією про захист прав і основних свобод (підписана представниками держав - початкових членів Ради Європи 4 листопада 1950 р.), Міжнародною конвенцією про ліквідацію всіх форм расової дискримінації (проголошена резолюцією Генеральної асамблеї ООН 25 листопада 1981 р.) (ст. 5), Документом Копенгагенської наради Конференції 3 людського виміру НБСЄ (прийнятий 29 червня 1990 р.)), як то «свобода думки, совісті і релігії», змішалися в працях правознавців, і як наслідок - на сторінках юридичних документів.

Загальна декларація 1948 року і новітні конституції говорять про «свободу думки, совісті і релігї̈». У зв'язку із цим вчені не можуть дійти згоди щодо того, чи існує тільки одна глобальна свобода розглянута в трьох різних аспектах, або слід розрізняти три самостійних виду свобод. Починаючи з п'ятдесятих і до кінця сімдесятих років більшість європейських вчених вважали за краще останній варіант, враховуючи конкретну мету релігійної свободи, але останнім часом схиляються до думки, що цей термін нерозривно пов'язаний зі свободою совісті.

Але навіть формулювання «свобода думки, совісті і релігї̈н не $\epsilon$ єдиним загальноприйнятим.

Наприклад, в Декларації ООН про ліквідацію всіх форм нетерпимості та дискримінації на основі релігії або переконань (проголошена резолюцією Генеральної асамблеї $00 \mathrm{H}$ 25 листопада 1981 р.), Документі Копенгагенської конференції з людського виміру НБСЄ (прийнятому 29 червня 1990 р.) використовується термін «свобода думки, совісті і релігії».

У Підсумковому документі Віденської зустрічі представників держав-учасниць Наради з безпеки і співробітництва в Європі (підписаний 15 січня 1989 р. представниками держав учасниць Наради з безпеки і співробітництва в Європі), Паризької хартії для нової Європи (підписана 21 листопада 1990 p. представниками держав-учасників Наради 3 безпеки i співробітництва в Європі) використовується термін «свобода думки, совісті, релігії і переконань».

А в Конвенції Співдружності Незалежних Держав про права та основні свободи людини (підписана 26 травня 1995 р. ратифікована 4 листопада 1995 р.) йдеться про «свободу думки, совісті і віросповідання».

При цьому головна проблема полягає в тому, що поняття свободи совісті і пов'язане з ним правове регулювання відносин, 
Права людини в Україні та у зарубіжних країнах: традиції та новації

що стосується «кожного», було зведено майже виключно до свободи віросповідань (тобто свободи, що стосується тільки індивідів, які вважають себе віруючими), і навіть більш того - до проблем діяльності релігійних об'єднань (колективної форми реалізації права на свободу віросповідань).

У результаті законодавство про свободу совісті стало сприйматися як «спеціальне», галузеве релігійне. Пріоритет віддається релігійним об'єднанням, а не людині, яка стає «придатком» конфесій. Право «кожного» на свободу совісті залишається в системі права лише декларативно, фактично перебуваючи поза правовим полем.

Про необхідність дати «змістовне, але гранично коротке визначення свободи совісті» говорив С. Лін, однак, в силу тієї ж традиції не зміг вийти за рамки, які прив'язують «це поняття до релігії» [27]. Зокрема, С. Лін свободу совісті визначає «як дозволене і гарантоване законами держави право громадян вільно і самостійно визначати своє ставлення до релігії, за умови дотримання законності і встановленого в країні правопорядку» [27].

С. Брукс під свободою совісті розуміє «право людини як вірити в Бога згідно з вченням тієї чи іншої вільно обраної ним релігії, так і бути атеїстом, тобто не вірити в Бога ... Свобода віросповідання означає право людини на вибір релігійного вчення i безперешкодного відправлення культів і обрядів відповідно до цього вчення» [28].

На думку Дж. Ханг, свобода совісті розуміється як «право кожної людини самостійно вирішувати питання про своє ставлення до релігії: бути віруючим або атеїстом. Свобода віросповідання передбачає право сповідувати індивідуально або спільно з іншими будь-яку релігію, право вільно вибирати, мати і поширювати релігійні переконання і діяти з ними» [29]. У підходах Дж. Ханг прив'язка свободи совісті до вищезазначених застарілих підходів значно менша, але повністю її уникнути не вдалося. Позиція Дж. Ханг $є$ послідовною і максимально коректною, оскільки взагалі не пов'язана 3 поняттям релігії. «Свобода совісті як суб'єктивне право кожної людини, включає в себе право формувати, вибирати, змінювати, відстоювати і поширювати переконання, право дотримуватися переконань і право відмовлятися від них, а також право діяти (не діяти) відповідно до переконань за умови правомірності зовнішніх проявів поведінки індивіда» [29].

Р. Адеола півкроку назад зробила дослідження і в деякій мірі зв'язала юридичний зміст права на свободу совісті 3 визначенням «релігії» [30]. У контексті дослідження проблеми 
реалізації свободи совісті, не менш актуальною $\epsilon$ проблема співвідношення особистої та колективної свободи.

Критикуючи «включення в свободу совісті свободи віросповідання в повному обсязі», автори пропонують «в складі свободи совісті вбачати наявність тільки індивідуальної свободи віросповідання в частині її природно-правових елементів, тоді як позитивно-правові елементи цієї свободи (права релігійних об'єднань, інститут таємниці сповіді та інші) залишаються за рамками свободи совісті і складають самостійний предмет свободи віросповідання» [31].

Аналіз реальної ситуації показує, що свобода совісті кожного $є$ заручницею самодостатніх відносин держави 3 релігійними об'єднаннями і державної віросповідної політики. А формальним приводом для домінування цих правовідносин служить нібито турбота про реалізацію прав віруючих (на свободу віросповідань), а насправді корпоративних інтересів конфесійної бюрократії і влади. Перші отримують від держави «спеціальні» пільги в обмін на політичну підтримку.

Тому більш коректною видається позиція, що виключає співвідношення індивідуального і колективного: 1) свобода совісті включає в себе все різноманіття правомірних проявів систем орієнтації (без прив'язки до понять «релігія», «віросповідання»); 2) свобода совісті включає індивідуальні або колективні форми; 3) колективна форма $\epsilon$ похідною від індивідуальної (в рамках реалізації права на об'єднання).

Свобода совісті, таким чином, включає в себе все різноманіття форм і систем світоглядної орієнтації, що реалізуються одноосібно і / або колективно на принципах рівності.

Якими ж представляються суттєвий зміст і значення свободи совісті, iї основні правові аспекти з урахуванням вимог і реалій початку XXI століття? Відповідь на це питання не однозначна і не беззаперечна.

Перш за все слід зазначити, що право кожної людини на свободу совісті $\epsilon$ юридичним виміром свободи світоглядного вибору (в т. ч. формувати, дотримуватися, вибирати і змінювати вже зроблений вибір), а також правомірної поведінки, заснованої на згаданому виборі. Це право є системоутворюючим в системі прав людини. Без його реалізації інші права людини втрачають більшу частину реального змісту, залишаючись декларацією.

Реалізуючи право на свободу совісті, людина усвідомлює себе, знаходить сенс і визначає своє місце в житті. Людське життя не можна «прожити», повторюючи видові зразки; людина сама повинна прожити своє життя. Можна припустити, що, 
Права людини в Україні та у зарубіжних країнах: традиції та новації

задовольняючи цю потребу, людина і стає власне людиною. Таким чином, свобода совісті - право на задоволення світоглядної потреби, надає сенс існуванню.

У цілому, незважаючи на деякий занепад конфесійного впливу на людську цивілізацію, навряд чи $є$ підстави говорити про зменшення потреби кожної людини в орієнтації і самоусвідомленні. Змінам підлягають лише форми реалізації цієї специфічної потреби внаслідок розвитку цивілізації. Старі форми еволюціонують або відмирають, поступаючись дорогою новим формам.

Можна припустити, що розвиток форм систем орієнтації нерозривно пов'язаний з еволюцією людства в цілому. Звідси необхідність рівноправності нових форм (в т. ч. перспективних, тих, що виникнуть в майбутньому) по відношенню до вже наявних. Тим більше що «споконвічні» форми були свого часу «новими». Наприклад, християнство свого часу було «новим» по відношенню до «традиційного» язичництва. Розвиток цивілізації зумовлює зміну співвідношення між наукою і релігією в суспільстві, між знанням і вірою кожної людини. Усвідомлення різноманіття відносин і повагу до співвідношення знання і віри у різних людей в суспільстві є головним аспектом свободи совісті в реаліях сучасності.

В юриспруденції ці принципи повинні знайти відображення в праві кожного на свободу совісті. Від реалізації цього системоутворюючого права залежать: здатність індивіда самореалізуватися як особистість; можливість подолати суперечності між тенденціями, зумовленими випереджаючим розвитком цивілізації і природою людини; здатність держави до сталого розвитку без соціальних вибухів і потрясінь; вміння світової спільноти знайти шляхи до вирішення глобальних проблем, що стоять перед людством.

Таким чином, свобода совісті - системоутворююче право в системі прав людини, основне невід'ємне право кожного на задоволення світоглядної потреби, надає сенс існуванню на основі вільного світоглядного вибору, а також правомірної поведінки, заснованого на згаданому виборі без обмеження в інших цивільних правах і свободах або їх втрати.

Зміст свободи совісті включає право індивідуально або спільно 3 іншими вільно формувати, обирати, змінювати, розповсюджувати переконання і діяти відповідно до них, не ущемляючи свободи і особистої гідності інших. Усвідомлення різноманіття відносин і повагу до співвідношення знання і віри у різних людей в суспільстві $\epsilon$ головним аспектом свободи совісті в реаліях сучасності. Свобода совісті $\epsilon$ стрижнем ідентичності 
людини - можна сказати, що це право бути людиною. Вільний світоглядний вибір $є$ основою вільного політичного вибору, правової демократії і соціальної держави. У міру трансформації правових і політичних систем поняття і зміст свободи совісті розглядається через призму прав і свобод людини, все більше розширюючись і звільняючись від прив'язки до юридично невизначеного терміну «релігія».

Водночас у сучасному науково-освітньому середовищі немає єдиного загальноприйнятого теоретико-правового визначення свободи совісті, а має місце тенденція до його розширення як свободи світоглядного вибору.

\section{Висновки}

У кінцевому підсумку недотримання принципу світоглядного нейтралітету держав створює грунт для конфліктів, а значить, i вкрай серйозні перешкоди на шляху позитивної інтеграції держав.

Серед стратегічних напрямків для зміни ситуації на краще слід виділити такі:

- розробка сучасної теоретико-правової моделі свободи совісті на основі нової парадигми (моделі), що усуває суперечності основоположних принципів і понятійного апарату;

- реформування універсальних міжнародно-правових документів у сфері свободи совісті на основі сучасної теоретикоправової моделі;

- реформування регіональних міжнародно-правових документів у сфері свободи совісті на основі сучасних теоретикоправових моделей і універсальних міжнародно-правових документів;

- реформування внутрішньодержавного правового інституту свободи совісті на основі сучасних теоретико-правових моделей і міжнародно-правових документів;

- формування і вдосконалення міжнародно-правової i внутрішньодержавної системи гарантій реалізації свободи совісті на основі принципу світоглядного нейтралітету держав та інших суб'єктів міжнародного права.

\section{Список використаних джерел:}

1. Робберс Р. Государства и религии в Европейском Союзе. Москва : Ин-т Европы РАН, 2019. 719 с.

2. Yarmol L. On freedom of belief and freedom of expression as natural (socially general) human rights: their notion and correlation. 
Studia z zakresu Prava, Administracji i zarzadzania uniwersytetu Kazimierza Wielkiego w Bydgoszczy. 2015. № 7. P. 71-80.

3. Kamal A. The Law of Cyber-Space. An Invitation to the Table of Negotiations. Geneva : United Nations Institute for Training and Research, 2015. URL : https://www.un.int/kamal/sites/www.un.int/ files/The $\% 20$ Ambassador $\% 27 \mathrm{~s} \% 20$ Club $\% 20$ at $\% 20$ the $\% 20$ United $\%$ 20Nations/the_law_of_cyber-space.pdf (date of access: 21.04.2021).

4. Yarmol L. On the right to peaceful assembly as a guarantee of freedom of expression: some reflections on Ukrainian law and practice. UR Journal of Humanities and Social Sciences. 2017. № 3(4). P. 114-126.

5. Mendel T. Freedom of Information as an Internationally Protected Human Right. Comparative Media Law Journal. JanuaryJune 2003. No. 1. URL : https://www.article19.org/data/ files/pdfs/publications/foi-as-an-international-right.pdf (date of access: 21.04.2021).

6. Sjors Ligthart, Freedom of thought in Europe: do advances in 'brain-reading' technology call for revision?, Journal of Law and the Biosciences, 2020; lsaa048, URL : https://doi.org/10.1093/jlb/lsaa048 (date of access: 21.04.2021).

7. William Schabas, The Universal Declaration of Human Rights: The Travaux Préparatoires (2013), at 283. See also the Plan of the Draft Outline of an International Bill of Rights, at 305-7.

8. Robert A. Mason and Marcel A. Just, Neural Representation of Physics Concepts, 27 Psychol. Sci. 904 (2016); Marcel A. Just et al., Machine Learning of Representations of Suicide and Emotion Concepts Identifies Suicidal Youth, 1 Nat. Hum. Behav. 911 (2017).

9. Christoph Bublitz, Freedom of Thought in the Age of Neuroscience, 100 Archiv für Rechts-und Sozialphilosophie 1 (2014), at 3; McCarthy-Jones, supra note 2, at 5; Cf. Vermeulen and Roosmalen, supra note 1, at 738.

10. The Charter of the United Nations was signed on 26 June 1945, in San Francisco. URL : https://www.un.org/en/about-us/uncharter (date of access: 21.04.2021).

11. Henry T. Greely, Mind Reading, Neuroscience, and the Law, in A Primer on Criminal Law and Neuroscience 121 (Stephen Morse and Adina L. Roskies eds., 2014). Healthc. Ethic. 446, 452 (2020); McCarthy-Jones, supra note 2, at 7.

12. The Universal Declaration of Human Rights (UDHR) was proclaimed by the United Nations General Assembly in Paris on 10 December 1948 (General Assembly resolution 217 A). URL : https://www.un.org/en/about-us/un-charter (date of access: 21.04.2021). 
Права людини в Україні та у зарубіжних країнах: традиції та новації

13. Donnikova, I., \& Kovban, A. (2020). Moral-legal self-regulation of freedom of conscience: culturological aspect. Amazonia Investiga, 9(32), 28-35.

14. Myshchak, I. (2019). Constitutional and legal guarantees of religious freedom in Ukraine: some shortcomings and gaps in current legislation. Constitutional process in Ukraine: political and legal aspects. No 10 (66). 3-7.

15. Kovban, A., Kohut, I. (2019). Formation of a Corporate Social Responsibility Strategy of Companies in EU Countries. Baltic Journal of Economic Studies. Vol 5, No 3 (2019). P. 82-90. DOI: https://doi.org/10.30525/2256-0742/2019-5-3-82-90.

16. Davidson, Helen. 2016. "Australia's politicians have promoted xenophobia: UN expert." The Guardian, November 18. URL : www.theguardian.com/australianews/2016/nov/18/australiasimmigrationpolicies-have-promoted-xenophobia-un-expert.

17. Deiss-Helbig, Elisa and Uwe Remer-Bollow. 2017. "Exploring the Impact of Local Presence on Attitudes towards Asylum Seekers." Paper prepared for the ECPR General Conference 2017, Oslo, September 1. URL : https://ecpr.eu/Filestore/ PaperProposal/978917e3-b578-4e7d-9efab83dfa852721.pdf.

18. Dunn, Carolyn. 2017. "Vietnamese-Canadian family's refugee story inspires new Heritage Minute." CBC News, June 20. URL : www.cbc.ca/news/canada/calgary/trinh-family-boatpeople-inspiresheritage-minute- 1.4167835 .

19. United Nations. 2016. "Racism, Xenophobia Increasingly Globally, Experts Tell Third Committee, amid Calls for Laws to Combat Hate Speech, Concerns over Freedom of Expression." GA/SHC/4182. Press release, November 1. URL : www.un.org/ press/en/2016/gashc4182.doc.htm.

20. Dempster, Helen and Karen Hargrave. 2017. "Understanding Public Attitudes Towards Refugees and Migrants." Overseas Development Institute Working Paper 512, June 2017. London, UK: Overseas Development Institute. URL : https://euagenda.eu/upload/ publications/untitled-92767-ea.pdf.

21. United Nations General Assembly. 2016. In safety and dignity: addressing large movements of refugees and migrants: Report of the Secretary-General. A/70/59, April 21. https://refugeesmigrants.un.org/sites/default/ files/in_safety_and_dignity_-_addressing_large_ movements_of_refugees_and_migrants.pdf.

22. Distasio, Madeline. 2016. "Why Localization Could Be the Key to Overcoming Xenophobia." Borgen Magazine, November. 
23. Zeng, G., Wang, L. \& Zhang, Z. Prejudice and xenophobia in COVID-19 research manuscripts. Nat Hum Behav 4, 879 (2020). URL : https://doi.org/10.1038/s41562-020-00948-y.

24. Zubashvili, N. (2020). Deconstructing and reconstructing attitudes towards immigrants: The case of Sweden [Master's thesis, Lund University]. Lund University Libraries. URL : http://lup.lub.lu.se/student-papers/record/9020672.

25. Ahuja KK, Banerjee D, Chaudhary K, Gidwani C. Fear, Xenophobia and collectivism as predictors of well-being during Coronavirus disease 2019: An empirical study from India.International Journal of Social Psychiatry. July 2020. doi:10.1177/0020764020936323.

26. Ahorsu, D. K., Lin, C. Y., Imani, V., Saffari, M., Griffiths, M. D., Pakpour, A. H. (2020). The Fear of COVID-19 Scale: Development and initial validation. International Journal of Mental Health and Addiction. URL : https://doi.org/10.1007/s11469-020-00270-8.

27. Brooks, S. K., Webster, R. K., Smith, L. E., Woodland, L., Wessely, S., Greenberg, N., Rubin, G. J. (2020). The psychological impact of quarantine and how to reduce it: Rapid review of the evidence. The Lancet, 395, 912-920.

28. Díaz, A., Beleña, Á., Zueco, J. (2020). The role of age and gender in perceived vulnerability to infectious diseases. International Journal of Environmental Research and Public Health, 17(2), 485.

29. Huang, J., \& Liu, R. (2020). Xenophobia in America in the Age of Coronavirus and Beyond. Journal of vascular and interventional radiology : JVIR, 31(7), 1187-1188. URL : https://doi.org/10.1016/ j.jvir.2020.04.020.

30. Romola Adeola (2020) Xenophobia and internal displacement in Africa: Defining protection and assistance through the Kampala Convention, South African Journal of International Affairs, 27:4, 493510, DOI: $10.1080 / 10220461.2020 .1874502$.

31. Md. Rabiul Awal, Rui Cao, Roy Ka-Wei Lee, and Sandra Mitrović. 2020. On analyzing annotation consistency in online abusive behavior datasets. arXiv:2006.13507.

32. Pinkesh Badjatiya, Manish Gupta, and Vasudeva Varma. 2019. Stereotypical bias removal for hate speech detection task using knowledge-based generalizations. In Proceedings of the World Wide Web Conference. 49-59. 